\title{
THE INFLUENCE OF SODIUM CHLORIDE REPLACEMENT WITH POTASSIUM CHLORIDE AS A CURING AGENT ON THE QUALITY OF TANNED PUFFERFISH (Arothon reticularis) SKIN
}

\author{
Raden Lukas Martindro Satrio Ari WIBOWO*, Emiliana ANGGRIYANI, Ragil YULIATMO
}

Department of Leather Processing Technology, Politeknik ATK Yogyakarta, Sewon, Bantul, 55281 Yogyakarta, Indonesia, alexius.lucaswibowo@gmail.com

Received: 23.03.2018

Accepted: 18.05 .2018

https://doi.org/10.24264/Ifj.18.2.4

THE INFLUENCE OF SODIUM CHLORIDE REPLACEMENT WITH POTASSIUM CHLORIDE AS A CURING AGENT ON THE QUALITY OF TANNED PUFFERFISH (Arothon reticularis) SKIN

ABSTRACT. The pufferfish skin is a by-product that is underutilized. Skin tanning is the prospect way to enhance the economic value of pufferfish skin. The tanning process is a long one, including the process of curing the skin. Sodium chloride is commonly used for curing the skin. However, sodium chloride can increase the total dissolved solids (TDS) that will be problematic in the environment. Potassium chloride can be used instead of sodium chloride. This study aims to determine the influence of substituting sodium chloride with potassium chloride on the quality of tanned pufferfish skin. Sodium chloride and potassium chloride were used in the skin curing process, while the storage time was $0,1,2$, and 3 weeks. The assays performed are salt concentration on the skin, scanning electron microscope (SEM), FTIR, and physical quality of tanned pufferfish skin. The results showed that the salt content of potassium chloride in the skin was more easily absorbed than the salt of sodium chloride. The SEM and FTIR tests, descriptively, show no significant difference. The physical quality of the pufferfish skin preserved using potassium chloride is better than that of sodium chloride. Potassium chloride deserves to be used as a substitute for sodium chloride.

KEYWORDS: pufferfish, skin curing, salt, sodium chloride, potassium chloride

\section{INFLUENTA ÎNLOCUIRII CLORURII DE SODIU CU CLORURA DE POTASIU CA AGENT DE CONSERVARE ASUPRA CALITĂTII PIELII DE PEŞTE- BALON (Arothon reticularis)}

REZUMAT. Pielea de peşte-balon este un produs secundar insuficient utilizat. Tăbăcirea pielii este modalitatea de a creşte valoarea economică a pielii de peşte-balon. Procesul de tăbăcire este îndelungat şi include procesul de conservare a pielii. Clorura de sodiu este utilizată în mod obişnuit pentru conservarea pielii. Cu toate acestea, clorura de sodiu poate creşte cantitatea de solide totale dizolvate (TDS), care este problematică pentru mediul înconjurător. Clorura de potasiu poate fi utilizată în locul clorurii de sodiu. Acest studiu are ca scop determinarea influenţei înlocuirii clorurii de sodiu cu clorura de potasiu asupra calităţii pielii tăbăcite de peşte-balon. În procesul de conservare s-au utilizat clorura de sodiu şi clorura de potasiu, iar timpul de depozitare a fost de 0, 1, 2 şi 3 săptămâni. S-au efectuat teste precum concentraţia de sare din piele, microscopia electronică de scanare (SEM), FTIR şi calitatea fizică a pielii tăbăcite de peşte-balon. Rezultatele au arătat că conţinutul de sare al clorurii de potasiu din piele a fost mai uşor absorbit decât sarea din clorura de sodiu. Testele SEM şi FTIR, din punct de vedere descriptiv, nu prezintă nicio diferenţă semnificativă. Calitatea fizică a pielii de peşte-balon conservată utilizând clorura de potasiu este mai bună decât cea conservată utilizând clorura de sodiu. Clorura de potasiu merită să fie utilizată ca înlocuitor pentru clorura de sodiu. CUVINTE CHEIE: peşte-balon, conservarea pielii, sare, clorură de sodiu, clorură de potasiu

\section{L'INFLUENCE DU REMPLACEMENT DU CHLORURE DE SODIUM PAR LE CHLORURE DE POTASSIUM COMME AGENT DE CONSERVATION SUR LA QUALITÉ DU CUIR DE POISSON-GLOBE (Arothon reticularis)}

RÉSUMÉ. Le poisson-globe est un sous-produit insuffisamment utilisé. Le tannage de la peau est le moyen d'augmenter la valeur économique de la peau du poisson-globe. Le processus de tannage est long et comprend le processus de conservation de la peau. Le chlorure de sodium est couramment utilisé pour la conservation de la peau. Cependant, le chlorure de sodium peut augmenter la quantité de solides dissous totaux (TDS), ce qui est problématique pour l'environnement. Le chlorure de potassium peut être utilisé à la place du chlorure de sodium. Cette étude vise à déterminer l'influence du remplacement du chlorure de sodium par le chlorure de potassium sur la qualité du cuir de poisson-globe. Le chlorure de sodium et le chlorure de potassium ont été utilisés dans le processus de conservation et le temps de stockage a été de $0,1,2$ et 3 semaines. On a effectué de tests comme la concentration de sel de la peau, la microscopie électronique à balayage (MEB), le FTIR et la qualité physique du cuir du poisson-globe. Les résultats ont montré que la teneur en sel du chlorure de potassium dans la peau a été plus facilement absorbée que le sel de chlorure de sodium. Les tests MEB et FTIR, du point de vue descriptif, ne montrent aucune différence significative. La qualité physique de la peau de poisson-globe conservée en utilisant du chlorure de potassium est meilleure que celle préservée en utilisant du chlorure de sodium. Le chlorure de potassium mérite d'être utilisé comme substitut du chlorure de sodium. MOTS-CLÉS: poisson-globe, conservation de la peau, sel, chlorure de sodium, chlorure de potassium

\footnotetext{
"Correspondence to: Raden Lukas Martindro Satrio Ari WIBOWO, Department of Leather Processing Technology, Politeknik ATK Yogyakarta, Jl. Ringroad Selatan, Glugo Panggungharjo, Sewon, Bantul, 55281 Yogyakarta, Indonesia, alexius.lucaswibowo@gmail.com
} 


\section{INTRODUCTION}

Pufferfish is a kind of fish that is classified in fish that cannot be used in the process of fishing in the sea. During this time the pufferfish is just thrown away and becomes beach and sea waste. Pufferfish is a unique fish because it has a round body shape, attractive color and has small spines on the surface of the skin [1]. Küçükakin et al. [2] also stated that fish skins have gained an increased interest in the leather industry for producing leathers with attractive and unique grain structure, due to their high potential as an additional raw material source of leather industry.

Generally, all types of fish skins from aquatic environments can be tanned even though in practice only a few fish species can produce skin that is soft, radiant, has good scales and can be produced into leather and shoes [3]. The need for leather as a fashion ingredient increases every year, whereas raw material for tanning is increasingly limited. Tanning the pufferfish skin can be an alternative to the problem.

The tannery process consists of a long stage and begins with skin curing. Skin curing is one of the important processes in a tannery because, with curing, skin quality can be maintained. Skin is an organic material that is resistant to the external environment, both chemically and biologically. Skin can be damaged due to the presence of proteolytic enzymes produced by bacteria or fungi. Proteolytic enzyme can degrade the protein in the skin and remove dead tissue. Following the broken tissue of the animal, these bacteria cause autolysis (self hydrolysis) of the collagen. This breaks down the protein to amino acids, which further break down to produce ammonia [4].

Sodium chloride salt is a chemical commonly used in the process of curing the skin. In the context of clean technology, it is useful to calculate the amount of salt used in the tannery globally. Physically, salt is a crystal-shaped white solid object that is a collection of compounds with the largest part of sodium chloride (>80\%) and other compounds such as magnesium chloride, magnesium sulphate, calcium chloride, and others [5] However, sodium chloride discharged in the soak liquor due to salt curing methods forms the largest component of most tanning effluents in terms of contribution to dissolved solids and chlorides in the effluents. Sodium chloride is the most difficult to treat and hence poses difficulties in the effluent treatment. They contribute in large measure to total dissolved solids (TDS) and to chlorides in the composite tannery effluent [6]. Sarker et al. [7] also state that this conventional technique is very popular due to the availability of common salt (sodium chloride) and its cost-effective procedure but it generates a huge pollution problem increasing salinity. As a result, an alternative method of using less or no salt for hide curing needs to be developed.

Another type of salt used for skin curing is potassium chloride [8]. Bailey and Gosselin [9] reported that curing animal hides and skins with potassium chloride in place of common salt has been carried out with steer hide by brine curing method. Potassium chloride is an almost perfect copy of sodium chloride curing without the environmental consequences associated with sodium chloride. Therefore, the substitution of sodium chloride with sodium chloride as a curing agent is worthy of further study.

\section{EXPERIMENTAL}

\section{Materials}

The materials of this research were 8 pieces of pufferfish skin obtained from traditional fish market in the District of Rembang (East Java, Indonesia), salts (sodium chloride and potassium chloride), distilled water, and chemicals for histological assay, Scanning Electon Microscope (SEM), Fourier Transmitted Infra Red (FTIR), and physical quality assay. The tools were blades, buckets, Baume meter, Becker glass, mixer, electric stove, incubator, scissors, and paper filter. 


\section{Methods}

\section{Leather Treatment}

After cleaning the remaining grease, blood, meat, and dirt, fresh skin was then soaked in saturated salt at the high level of salt concentrations (salinity) $20-24^{\circ} \mathrm{Be}$. Concentrations of salt should not be under $20^{\circ} \mathrm{Be}$. The salinity levels were measured with an instrument called Baume meter. The pufferfish skin were soaked in various salts (sodium chloride and potassium chloride) and curing time (0, 1 , 2 , and 3 weeks). The cured skin samples were collected every week.

\section{Determination of Sodium Chloride Concentration}

Chloride concentration was determined by classical Mohr [10] titration. Residual brine samples were diluted $(1: 100 \mathrm{v} / \mathrm{v})$ in nano-pure water prior to titration. All samples were run in triplicate.

\section{Physical Testing of Leather Samples}

The samples for physical testing were obtained as per IULTCS methods [11]. The samples were conditioned at $80.4^{\circ} \mathrm{F}\left(27^{\circ} \mathrm{C}\right)$ and 65.2 \% R.H. for 48 hrs. Physical properties such as tensile strength and percentage of elongation were investigated as per standard procedures. Each value reported is an average of four (2 along the backbone, 2 across the backbone) measurements.

\section{Analysis of Functional Group Using FTIR Spectrophotometer}

Analysis of functional group using Perkin Elmer FTIR (Chicago, USA) equipped with universal Attenuated Total Reflectance (ATR) diamond/ZnSe crystal at room temperature. Tanned pufferfish skin FTIR spectra were in the 500-4000 per $\mathrm{cm}$ range and collected in four scans with automatic signal gain control at a resolution of 16 per $\mathrm{cm}$ against a background spectrum recorded from a clean, empty cell. FTIR was conducted with a mid_IR deuterated triglycine sulfate detector and optical $\mathrm{KBr}$ beam splitter.

\section{Determination of Morphology}

Analysis of the tanned pufferfish skin morphology was observed by Scanning Electron Microscope (SEM) type JEOL JSM-5310 LV at 4000 times magnification for a flat crosssectional area.

\section{Data Analysis}

The data of sodium chloride and potassium chloride concentration, tensile strength, and percentage of elongation were described as the Mean \pm SD. Data were analyzed using $2 \times 4$ factorial analysis. Especially for data of sodium chloride and potassium chloride concentration in pufferfish skin were also analyzed using one way ANOVA analysis. Then followed by Duncan's multiple-range test (DMRT) using software SPSS Inc., (Chicago, IL, USA). Differences considered significant when the probability was less than $5 \%$. Another data were conducted with descriptive method.

\section{RESULTS AND DISCUSSIONS}

\section{Sodium Chloride Concentration}

The concentration of sodium chloride and potassium chloride in pufferfish skin was showed in Table 1. Based on the results, the longer curing time by salting the higher salt concentration in the skin. It indicates that skin takes time to fully absorb the sodium chloride in the salt. It makes the skin more resistant to decay that was caused by microorganisms, so the quality of fresh skin will be maintained [5]. Strumylaite et al. [12] also state that the effects of salt as a curing agent is a high osmotic property so as to solve the microbial cell membranes. When microorganisms are placed in a concentrated salt solution (30-40\%), the water in the cells would be out by osmosis and the cells undergo plasmolysis and will be hampered in breeding. However, based on the statistic analysis, potassium chloride can be absorbed by skin significantly $(\mathrm{P}<0.05)$ quicker than sodium chloride. Curing by potassium chloride significantly increases the potassium chloride concentration in skin every week, while curing by sodium chloride increases the sodium chloride concentration after 3 weeks. 
Table 1: Sodium chloride and potassium chloride concentration in Pufferfish skin (\%)

\begin{tabular}{|c|c|c|c|c|c|}
\hline \multirow{2}{*}{ Type of salt } & \multicolumn{4}{|c|}{ Curing time (week) } & \multirow{2}{*}{ Mean* } \\
\hline & 0 & 1 & 2 & 3 & \\
\hline Sodium chloride & $47.20 \pm 0.5$ & $51.79 \pm 1.9$ & $50.45 \pm 0.4$ & $54.07 \pm 3.5$ & $50.88 \pm 3.0$ \\
\hline Potassium chloride & $45.56 \pm 0.5$ & $60.30 \pm 1.1$ & $63.01 \pm 0.8$ & $91.79 \pm 0.2$ & $65.17 \pm 35.8$ \\
\hline Mean & $46.38 \pm 1.0^{x}$ & $56.04 \pm 4.9^{y}$ & $56.73 \pm 7.3^{y}$ & $71.93 \pm 21.9 .7^{2}$ & \\
\hline
\end{tabular}

Results are given as mean \pm standard deviation

${ }^{x y z}$ Different letters within the same row indicate statistical significance at $p<0.05$ level

Pickling salt is a major contributor to pollution of salt by tannery plant, so a substitute friendlier for the environment must be sought to cure skin. Wu et al. [13] have examined the replacement of sodium chloride with potassium chloride with the result that the skin is cured with potassium chloride, and the resulting tanned skin has the same quality as that cured with sodium chloride. Potassium chloride can be used as an alternative curing salt (sodium chloride). This salt is safe to use as a curing agent and the effluent does not harm plants, but is actually beneficial to plants as a nutrient.

\section{SEM Analysis}

The skin surface was analyzed using SEM. Images are taken to analyze the morphology of the skin surface of tanned pufferfish skin. It is observed from the skin surface that collagen fibers braided compactly into each other forming a matrix. Spines are fixed firmly between the weave [13]. The projection of the spiny ends can
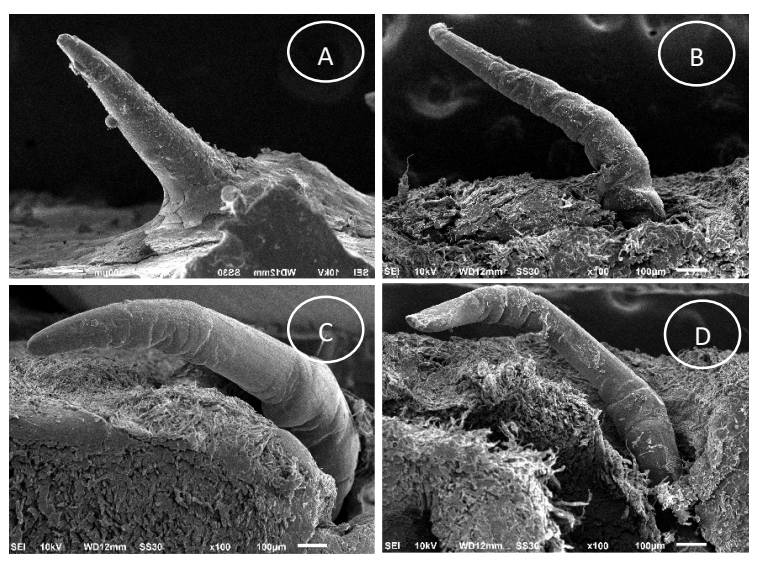

Figure 1. Scanning Electron Microscope (SEM) images of pufferfish skin preserved by sodium chloride in various weeks. A: 0 week; B: 1 weeks; C: 2 weeks, D: 3 weeks. be seen from Figures 1 and 2. The longer time of curing skin the more damaged the structure of the skin, resulting in a weak spinal shape. In SEM images of skin cured with sodium chloride and potassium chloride, it can be observed that there was a difference in the shape of the spine in the $3^{\text {rd }}$ week of curing. Wibowo et al. [1] state that the spine of the pufferfish consists of collagen protein shrouded by keratin. Skin damage is thought to be due to the presence of microorganisms such as collagenolytic and keratinolytic bacteria that begin to grow on the skin surface during the second week so that the enzymes produced by bacteria degrade collagen and keratin proteins [5].

Curing using sodium chloride can maintain the outer surface of the spine erect until the first week, but in the second week the spine is no longer erect and looks brittle the following week, but the outer shape of the spinal can still be clearly seen. It is almost the same process of skin curing as when using potassium chloride, but by
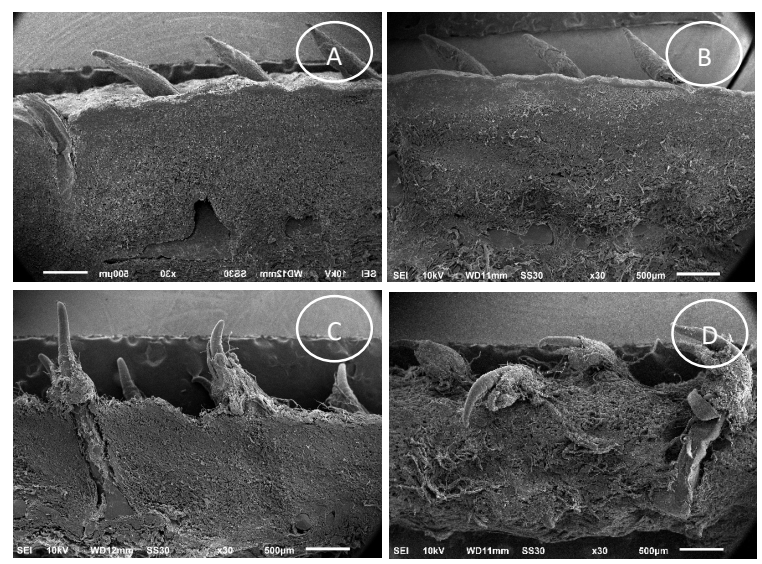

Figure 2. Scanning Electron Microscope (SEM) images of pufferfish skin preserved by potassium chloride in various weeks. A: 0 week; B: 1 week; C: 2 weeks, D: 3 weeks. 
the third week, the spinal form looked damaged. According to Wu et al. [14], sodium chloride has similar physical and chemical properties to potassium chloride but is very much different in one respect. While sodium chloride has negative effects on the growth of microorganisms when applied to the soil, potassium chloride is a fertilizer that encourages plant growth and does not result in the environment problems that are associated with saturated brine.

\section{FTIR Analysis}

The absorption at wavelength 650-4000 $\mathrm{cm}^{-1}$ were investigated and was showed in
Figures 3 and 4. This qualitative analysis showed that all the spectra of the leather samples were almost the same. This is because leather is made up of protein which is collagen, the major protein from which skin is formed [15]. The spectra display a broad band in the range 3650-3000 $\mathrm{cm}^{-1}$ that belongs to the stretching vibrations of the coordinated water molecules [16]. The band located at $1627-1647 \mathrm{~cm}^{-1}$ may be assigned to the vibrations of the $-\mathrm{OH}$ groups coordinated at the $\mathrm{Cr}(\mathrm{III})$ cation [17].

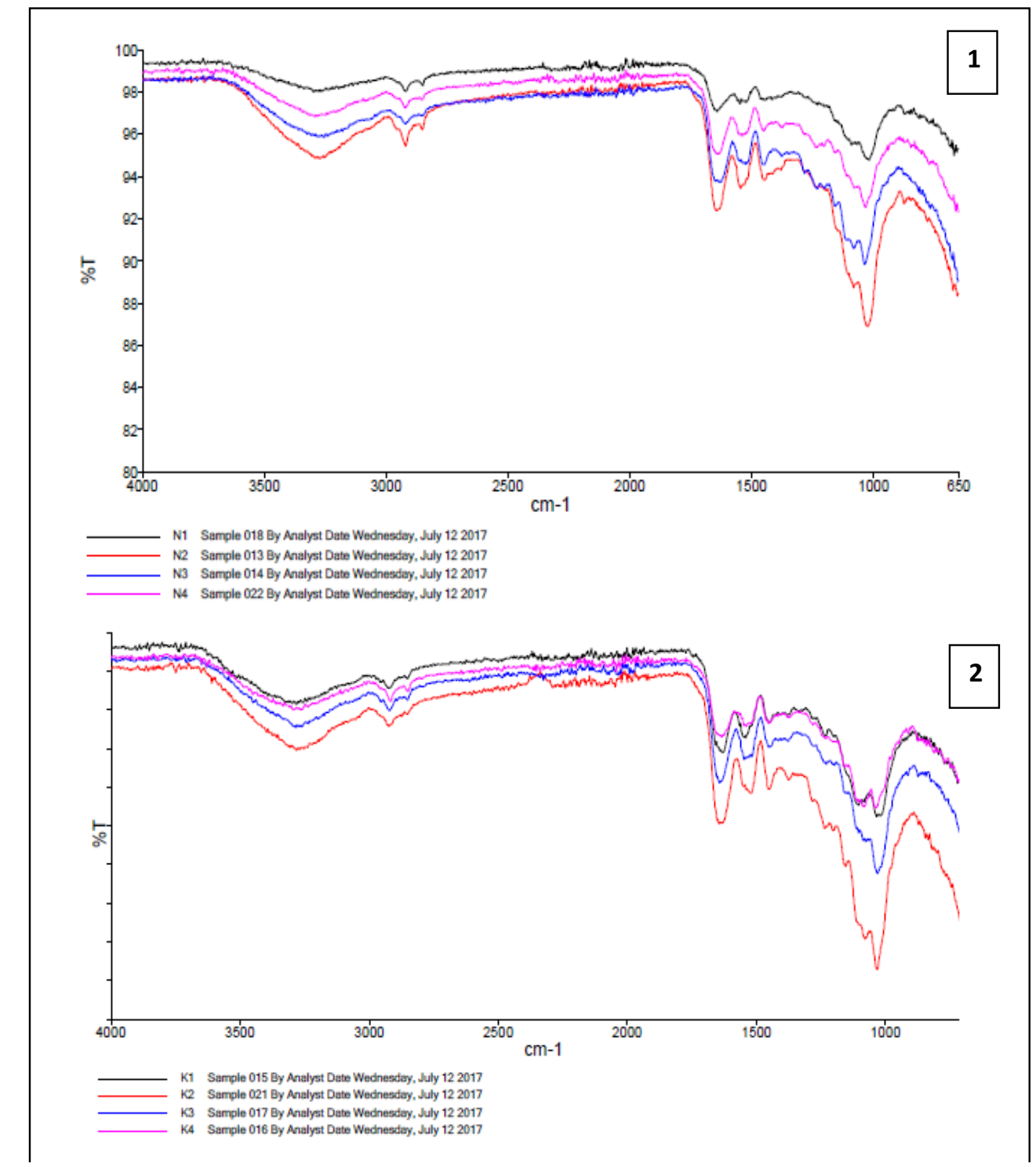

Figure 3. 1: Results of FTIR of tanned pufferfish skin by sodium chloride in various weeks; 2 : Results of FTIR of preserved pufferfish skin by potassium chloride in various weeks; N1: 0 week; N2: 1 weeks, N3: 2 weeks; N4: 3 weeks. K1: 0 week; K2: 1 weeks, K3: 2 weeks; K4: 3 weeks 
Table 2 shows the tensile strength of the tanned pufferfish skin. From this table, it can be observed that the tanned skins cured by potassium chloride have significantly better tensile strength $(P>0.05)$ than tanned skins cured by sodium chloride. On the other hand, curing time did not effect to tensile strength of tanned pufferfish skin. Strength values are agreeable in comparison with upper leathers [13]. However, Table 3 shows the significant effect of curing time of pufferfish skin $(P<0.05)$ on the percentage of elongation of tanned pufferfish skin, while the type of curing agent did not have much effect on the elongation of the tanned skin.

Table 2: Tensile strength of cured skin $\left(\mathrm{kg} / \mathrm{cm}^{2}\right)$

\begin{tabular}{|c|c|c|c|c|c|}
\hline \multirow{2}{*}{ Type of salt } & \multicolumn{4}{|c|}{ Curing time (week) } & \multirow{2}{*}{ Mean* } \\
\hline & 0 & 1 & 2 & 3 & \\
\hline Sodium chloride & $8.62 \pm 2.3$ & $7.14 \pm 0.8$ & $6.63 \pm 2.0$ & $4.49 \pm 1.0$ & $6.92 \pm 2.0^{a}$ \\
\hline Potassium chloride & $6.50 \pm 0.8$ & $9.97 \pm 1.8$ & $9.92 \pm 0.7$ & $8.09 \pm 2.1$ & $8.58 \pm 1.9^{b}$ \\
\hline Mean $^{\text {ns }}$ & $7.56 \pm 1.9$ & $8.56 \pm 1.9$ & $8.27 \pm 2.2$ & $6.89 \pm 2.5$ & \\
\hline
\end{tabular}

Results are given as mean \pm standard deviation

${ }^{a b}$ Different letters within the same row indicate statistical significance at $p<0.05$ level

NS means non significant difference at $P>0.05$ level

Table 3: Percentage of elongation of tanned pufferfish skin (\%)

\begin{tabular}{|c|c|c|c|c|c|}
\hline \multirow{2}{*}{ Type of salt } & \multicolumn{4}{|c|}{ Curing time (week) } & \multirow{2}{*}{ Mean ${ }^{\text {ns }}$} \\
\hline & 0 & 1 & 2 & 3 & \\
\hline Sodium chloride & $25.98 \pm 11.5$ & $32.41 \pm 0.1$ & $47.46 \pm 0.4$ & $49.56 \pm 0.2$ & $38.85 \pm 11.5$ \\
\hline Potassium chloride & $33.76 \pm 1.7$ & $34.87 \pm 3.6$ & $37.99 \pm 2.96$ & $41.01 \pm 2.4$ & $36.91 \pm 3.7$ \\
\hline Mean & $29.87 \pm 8.1^{x}$ & $33.64 \pm 2.5^{x}$ & $42.72 \pm 5.7^{y}$ & $45.29 \pm 5.1^{y}$ & \\
\hline
\end{tabular}

Results are given as mean \pm standard deviation

${ }^{x y 2}$ Different letters within the same column indicate statistical significance at $p<0.05$ level

NS means non significant difference at $\mathrm{P}>0.05$ level

It is the similar properties of the two salts that allow skins and hides to be soaked with potassium chloride in the same way as $\mathrm{NaCl}$ [18]. Bailey and Gosselin [16] proved that potassium chloride can be substituted for sodium chloride to produce brine cured hides. It can be done in paddles, raceways, processors or salt packs and in most respects will require almost no change in current brine curing facilities. They reported experimentally and commercially curing cattle hides, calfskins and pigskins with potassium chloride. The overall results suggest virtually no difference between the quality of hides and skins produced by this curing method compared to traditional curing with sodium chloride. However, at the same time, their research reported that the limited pressure on sodium chloride in packing house effluents precluded the use of this material for curing.

\section{CONCLUSIONS}

The quality of tanned pufferfish skin cured using potassium chloride is almost the same with that of skin cured using sodium chloride. Potassium chloride is worth using as a substitute for sodium chloride as a curing agent.

\section{Acknowledgements}

The authors wish to thank the financial support from Polytechnic ATK research grant Kemenperin (Ministry of Industry Republik Indonesia) 2016. 


\section{References}

1. Wibowo, R.L.M.S.A., Bachruddin, Z., Fitriyanto, N.A., Nakagawa, T., Hayakawa, T., Pertiwiningrum, A., Screening and characterization of keratinolytic bacteria from pufferfish skin waste, Pakistan J Nutr, 2017, 16, 7, 488-496, https://doi.org/10.3923/ pjn.2017.488.496.

2. Küçükakin, E., Zengin, A.C.A., Deveci, R., Örk, N., Zengin, G., Bitlisli, B.O., Histological, histochemical and chemical study on Katsuwonus pelamis fish skins, Revista de Pielărie Încălţăminte (Leather and Footwear Journal), 2016, 16, 4, 299-312, https://doi. org/10.24264/Ifj.16.4.5.

3. O'Flaherty, F., Roddy, W.T., Lollar, R.M., The chemistry and technology of leather, 1958, Vol 2, Reinhold Publishing Company, New York, pp. 165-200.

4. Vankar, P.S., Dwivedi, A.K., Raw skin preservation through sodium salts $-A$ comparative analysis, Desalination, 2009, 249, 158-162, https://doi.org/10.1016/j. desal.2008.08.011.

5. Covington, A.D., Tanning Chemistry, 2009, RSC Publishing. Cambridge, UK.

6. Luvdik, J., Cleaner tanning technologies, Proc Symp Cleaner Tanning Technol UNIDO, 21-25 September 1998, p. 13.

7. Sarker, M.I., Long, W., Liu, C.K., Preservation of Bovine Hide using Less Salt with Low Concentration of Antiseptic, Part I: Effectiveness of Developed Formulations, J Am Leather Chem As, 2018, 113, 1, 12-18.

8. Kanagaraj, J., Babu, N.K.C., Alternative to salt curing technique - A review, I Sci Ind Res India, 2002, 61, 339-348.
9. Bailey, D.G., Gosselin, J.A., The preservation of animal hides and skins with potassium chloride, J Am Leather Chem As, 1996, 91, 12, 317-333.

10. Pierce, Haeriisch and Sawyereds (eds.), Quantitative Analysis, 4" ed., 1958, John Wiley \& Sons Inc., New York.

11. IUP 6, Measurement of tensile strength and percentage elongation, JSLTC, 2000, 84, 317.

12. Strumylaitè, L., Žičkutè, J., Dudzevičius J., Dregval, L., Salt-preserved foods and risk of gastric cancer, Medicina (Kaunas), 2006, 42, 2, 1644-170.

13. Alla, J.P., Ramanathan, G., Fathima, N.N., Fish skin and exotic leathers, J Am Leather Chem As, 112, 2017, 36-43.

14. Wu, J., Zhao, L., Liu, X., Chen, W., Gu, H., Recent progress in cleaner preservation of hides and skins, J Clean Prod, 2017, 148, 158-173, https://doi.org/10.1016/j. jclepro.2017.01.113.

15. Mirghani, M.E.S., Salleh, H.M., Che Man, Y.B., Jaswir, I., Rapid authentication of leather and leather products, Adv Nat Appl Sci, 2012, 6, 5, 651-659.

16. Stefanescu, M., Barbu, M., Vlase, T., Barvinschi, P., Barbu-Tudoran, L., Stoia, M., Novel low temperature synthesis method for nanocrystalline zinc and magnesium chromites, Thermochim Acta, 2011, 526, 130-136, https://doi.org/10.1016/j. tca.2011.09.005.

17. Abdel-Aal, E.A., Farghaly, F.E., Tahawy, R., Elshahat, M.F., A comparative study on recovery of chromium from tannery wastewater as nano magnesium chromite, Physicochem Probl Miner Process, 2016, 52, 2, 821-834, https://doi.org/10.5277/ppmp160224. 
18. Bailey, D.G., The preservation of hides and skins, J Am Leather Chem As, 2003, 98, 8, 308319.
(C) 2018 by the author(s). Published by INCDTPICPI, Bucharest, RO. This is an open access article distributed under the terms and conditions of the Creative Commons Attribution license (http:// creativecommons.org/licenses/by/4.0/). 